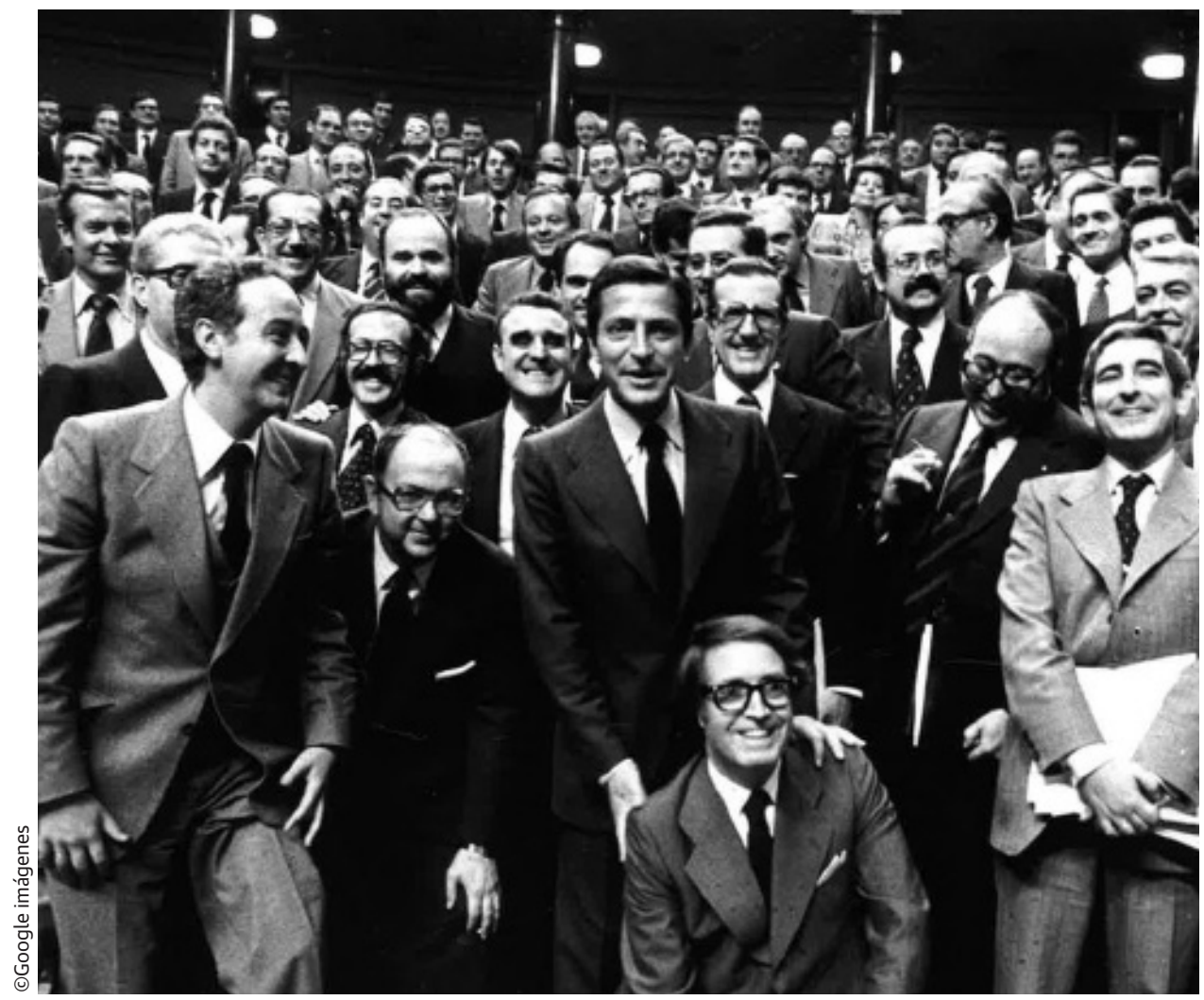

\title{
REMEMORACIÓN HISTÓRICA EN EL DOCUMENTAL DE ENTREVISTA DE LA TRANSICIÓN ESPAÑOLA
}

\author{
HISTORICAL REMEMBRANCE \\ IN THE DOCUMENTARY INTERVIEW \\ OF THE SPANISH TRANSITION
}

Pedro Sangro Colón / psangroco@upsa.es UNIVERSIDAD PONTIFICIA DE SALAMANCA 


\section{RESUMEN}

El grueso de la filmografía que ocupan los largometrajes documentales estrenados durante el periodo de la Transición española caracteriza su discurso por una profusa revisión del pasado histórico -sobre todo la Guerra Civil y el periodo franquista- y un empleo recurrente de la entrevista como epicentro de su enunciación -sus protagonistas toman la palabra en calidad de testigo o narrador-, con la intención de dar cabida a voces alternativas a la de la versión de los hechos pretéritos impuesta por décadas de dictadura. Ese corpus de filmes se propone no tanto recordar lo sucedido como rememorarlo: construir un relato del mismo de forma selectiva y con conciencia del presente al que sirve: el cambio político, social y cultural en tránsito. Empleando como metodología el análisis textual fílmico, el presente artículo persigue determinar la contribución de los documentales de entrevista en la cimentación de la memoria histórica de la sociedad española que experimentó el paso de la dictadura a la democracia. En su exposición de resultados, establece tres categorías de películas documentales diferenciadas por sus intenciones en la rememoración planteada: la "memoria de los perdedores" que ensalza a las víctimas de la guerra y cuestiona frontalmente la figura de Franco y su ideario, las "memorias militantes" que plantean reivindicaciones, alegatos y denuncias desde la efervescencia del debate de la lucha por las libertades de la Transición, o las "memorias biográficas", que hacen pública la represión acumulada durante años de dictadura en contextos de intimidad, permitiendo extrapolar su experiencia a la sociedad de entonces.

PALABRAS CLAVE: Transición, documental, entrevista, análisis fílmico, memoria histórica.

\section{ABSTRACT}

The majority of the filmography composed by the full-length documentaries released during the Spanish Transition to democracy (1976-1982) focuses its attention on exhaustively revisiting recent History, especially the Civil War and the Francoist dictatorship. It also recurrently uses interviews as the epicentre of its discourse -its protagonists speak up as witnesses or narrators- with an aim to allow alternative voices to the official version of past events imposed during the decades of dictatorship. This body of films aims at, rather than recalling what happened, making a remembrance of it; building an account of it selectively and with an awareness of the present it tries to serve: the ongoing political, social, and cultural change. Using film textual analysis as a methodology, this paper aims at determining the contribution of documentary interviews in laying the foundation of the historical memory of the Spanish society that was experiencing a transition from dictatorship to democracy. In the report of results, three categories of documentaries, which can be distinguished depending the intentions behind the remembrance, are established: the "memory of the losers", praising the victims of the war and openly questioning Franco's figure and ideology; the "activist memories", which propose vindications, allegations and complaints in the highly spirited debate on the fight for freedom during the Spanish Transition to democracy; or the "biographical memories", which disclose the repression that had been piling up during years of dictatorship in contexts of intimacy, and which leads to extrapolate those experiences to the society of that time.

KEYWORDS: Transition, Documentary, Interview, Film Analysis, Historical Memory

Recibido: 10 de marzo de 2015 Aceptado: 29 de septiembre de 2015 


\section{LA REMEMORACIÓN DEL PASADO}

El protagonismo de los medios audiovisuales en nuestra sociedad provoca, en muchas ocasiones, que el común de los espectadores los considere como la principal fuente de provisión documental de la historia pretérita. El cine juega también un importante papel en ello, convirtiéndose en destacado foco de conocimiento histórico para una gran parte de la ciudadanía ${ }^{1}$. Como señala Huguet, la fragua de hipótesis y la interpretación del pasado que ejerce el historiador a partir de los documentosdisponibles se ayuda del material cinematográfico como una fuente documental más, pues su discurso "ahorma su narración acerca de un sujeto de interés, en un tiempo y en un lugar determinados"2. La irrupción del filme como elemento de apoyo a la historiografía ha provocado un debate que últimamente se inclina por asumir su aportación complementaria y no excluyente a la Historia escrita ${ }^{3}$.

Desde esta perspectiva, el cine español producido durante los años de la Transición adquiere una especial relevancia por la relación que establece con el tiempo histórico en que vio la $\mathrm{luz}^{4}$. Como señala Palacio, la cinematografía de aquel momento fue capaz de concebir y transmitir al público "un cierto estado de conciencia favorable a las ideas que vertebraron la transformación política”5. Para lograrlo, el cine se afanó en la construcción de una memoria histórica cuyo propósito era elaborar un relato intelectual y emocional del pasado que facilitase la apertura del proceso democrático, fruto del consenso de la sociedad protagonista del momento presente desde el que se miraba atrás.

Para Pierre Nora, desde una perspectiva patriótica, la memoria histórica se edifica sobre los lugares geográficos y los objetos simbólicos del presente $^{6}$. Por su parte Maurice Halbawachs la define como un proceso social de reconstrucción del pasado que ayuda a la sutura de la identidad del grupo hoy? ${ }^{7}$ Tzvetan Todorov señala,en cambio, sus peligros, advirtiendo de su abusiva parcialidad en el recuerdo y su desapego a la objetividad de la Historia ${ }^{8}$. También Santos Juliá redunda en la vinculación afectiva de quien re- memora como elemento interesado para dotar de significado al presente ${ }^{9}$. Y Pedro Ruiz Torres recuerda las relaciones de poder y los intereses que tercian en los grupos sociales que esgrimen la historia bajo el estandarte de la memoria ${ }^{10}$.

Siendo un concepto complejo y matizable, la memoria histórica conlleva siempre un ejercicio exploratorio del ayer que un grupo social ejerce como laborcatártica o paliativa con respecto de los episodios más traumáticos acontecidos previamente en su comunidad. La Guerra Civil y las décadas de franquismo se erigen como dos capítulos recurrentes a los que la memoria apela a través del medio fílmico durante la Transición. Pero la producción cinematográfica del periodo no pretende recordar lo sucedido, sino rememorarlo, es decir, construir su narración de forma voluntaria, activa, plural y escindida en contradicciones, sin ocultar en ningún momento que su formulación se realiza desde el presente y de forma profundamente selectiva ${ }^{11}$.

\footnotetext{
1 ROSENSTONE, Robert. A., El pasado en imágenes. El desafío del cine a nuestra idea de la historia, Ariel, Barcelona, 1997, p. 29.

2 HUGUET, Montserrat, "La memoria visual de la historia reciente", en La mirada que habla: cine e ideología (Camarero, Gloria, ed.), Akal, Madrid, 2002, p. 18

3 Cfr. FERRO, Marc, Historia contemporánea y cine, Ariel, Barcelona, 1995, pp. 21-27.

4 En las dos últimas décadas se ha publicado numerosos estudios dedicados al cine español de la Transición, desde: MONTERDE, José Enrique, Veinte años de cine español. Un cine bajo la paradoja (1973-1992), Paidós, Barcelona, 1993; hasta el más reciente: SÁNCHEZ NORIEGA, José Luis (ed.), Filmando el cambio social. Las películas de la Transición, Laertes, Barcelona, 2014.
}

5 PALACIO, Manuel "Introducción", en El cine y la transición política en España (1975-1982) (Palacio, Manuel, ed.), Biblioteca Nueva, Madrid, 2011, p. 9.

6 NORA, Pierre (ed.), Les lieux de mémoire, Gallimard, Paris, 1997.

7 HALBWACHS, Maurice, La mémoire collective, P.U.F., Paris, 1968. 8 TODOROV, Tzvetan, Los abusos de la memoria, Paidós, Barcelona, 2000.

9 JULIÁ, Santos, Elogio de la Historia en tiempo de Memoria, Marcial Pons-Fundación Alfonso Martín Escudero, Madrid, 2011.

10 RUIZ TORRES, Pedro, "Los discursos de la memoria histórica en España", Hispania Nova. Revista de Historia contemporánea, n07 (2007), [http://hispanianova.rediris.es/7/ dossier/07d001.pdf] (última consulta: 27/09/2015).

11 DEL ÁGUILA, Rafael, "Desmemoria y rememoración: la guerra y el franquismo hoy", Historia y Política, no 16 (2006), pp. 184-187. 
La perspectiva que guía la rememoración cinematográfica del pasado inmediato en el tiempo de la Transición española es asumida, sobre todo, por la vertiente documentalista. A las puertas de la democracia, el género está ausente de las pantallas debido a la imposición del Noticiario Cinematográfico Español (No-Do), un monopolio audiovisual al servicio de la propaganda turística y política del régimen franquista que gozóhasta finales de los setentade la exclusividad de la información cinematográfica y la obligación de su proyección en salas. No ha de extrañar, entonces, que tras su declive y posterior desaparición el género documental experimentase un incremento cuantitativo inédito-irrepetible hasta finales de la década de los noventa ${ }^{12}$, a pesar de las dificultades para la distribución y exhibición que encontró en su camino en forma de censura indirecta, trabas administrativas o intervencionismo estatal ${ }^{13}$.

No son numerosas las películas documentales producidas durante la Transición que centren su atención en el presente ${ }^{14}$. El grueso de la filmografía documental del periodo caracteriza su discurso por su profusa revisión del pasado histórico -como ya señalamos, la reelaboración del relato conocido sobre la Guerra Civil y el franquismo- con la intención de dar la palabra a voces alternativas a la versión impuesta por la dictadura. Partiendo de este contexto, el presente artículo se centra en el análisis textual de los largometrajes documentales cinematográficos producidos durante la Transición española $(1976-1982)^{15}$ que poniendo el acento en la rememoración del pasado, emplean la entrevista como elemento central de su discurso. El objetivo de dicho análisis es determinar su contribución como textos en la fragua de la memoria histórica de la sociedad española que experimentó el tránsito de la dictadura a la democracia ${ }^{16}$.

Aunque los filmes de naturaleza documental presenten una asepsia que parece acercarles más a la objetividad de los vestigios escritos, no deben ser considerados un reflejo directo de la realidad, pues como señala Rosenstone, "conforman un discurso narrativo con un significado de- terminado"17. El objeto de estudio que nos ocupa, compuesto por el conjunto de documentales en los que las entrevistas adquieren un protagonismo indiscutible, erradica en todos los casos cualquier asomo de objetividad para exhibir sin tapujos su condición discursiva ${ }^{18}$. Partiendo de esta consideración, la metodología empleada toma como referencia el modelo de análisis textual fílmico que propone Sánchez Noriega ${ }^{19}$. Su resul-

12 HERNÁNDEZ RUIZ, Javier y PÉREZ RUBIO, Pablo, Voces en la niebla. El cine durante la transición española (1973-1982), Paidós, Barcelona, 2004, p. 116.

13 PÉREZ PERUCHA, Julio y PONCE, Vicente, "Algunas instrucciones para evitar naufragios metodológicos y rastrear la Transición democrática en el cine español", en PALACIO, Manuel (ed.), op. cit., 259.

14 Curiosamente, los ejemplos más destacados coinciden en la revisión crítica del proceso de normalización democrática contemporáneo a su producción: Numax presenta (Joaquim Jordà, 1979), Informe general sobre algunas cuestiones de interés general (Pere Portabella, 1976), o bien el díptico Después de... $1^{\text {a }}$ parte. No se os puede dejar solos y Después de... $2^{\mathrm{a}}$ parte. Atado y bien atado (Cecilia y José Juan Bartolomé, 1981).Se puede consultar al respecto el volumen de GÓMEZ VAQUERO, Laura, Las voces del cambio. La palabra en el documental de la Transición en España, Ayuntamiento de Madrid, Madrid, 2012.

15 Consideramos, para su análisis, los largometrajes documentales estrenados en este lapso temporal, entre el referéndum de la Reforma Política y la llegada del primer gobierno socialista al poder -incluiremos excepcionalmente algún título producido anteriormente en la clandestinidad, pero conocido por el público en el marco temporal determinado-.

16 Queda fuera de nuestro estudio el díptico de Basilio Martín Patino Canciones para después de una guerra (1971) y Caudillo (1977), pues su contribución a la rememoración histórica del periodo se ejerce desde un modelo enunciativo alejado del documental de entrevista. Ambos son "documentales de montaje", definidos por García Martínez como películas que se sirven exclusivamente de imágenes de archivo y de las que se apropia el director en su texto fílmico.

17 ROSENSTONE, Robert A., op. cit., 35.

18 Cfr. MONTERDE, José Enrique, op. cit., pp. 153-154.

19 Este modelo de análisis incluye: Ficha técnica de producción. Sinopsis argumental. Contexto de producción y recepción de la película (ideología de la época, política, rutinas de producción, claves genéricas y relevancia de los autores). Análisis de los elementos formales (visuales, sonoros y sintácticos). Análisis de los elementos narrativos (enunciación y punto de vista, construcción temporal, estructura, personajes y escenarios). Análisis de los elementos temáticos y de contenido (temas, motivos y argumentos). Hermenéutica, crítica y recepción. Cfr. SÁNCHEZ NORIEGA, José Luis, Historia del cine. Teoría y géneros cinematográficos, fotografía y televisión, Alianza editorial, Madrid, 2001, pp. 61-66. 
tado determina la existencia de tres categorías documentales diferenciadas en sus pretensiones, pero coincidentes en el presupuesto común de las películas que incluyen: la rememoración pretérita a través de la palabra dada a diferentes personajes que asumen el estatus de testigo o narrador.

\subsection{La memoria de los perdedores: la guerra y el dictador}

Un primer bloque de documentales incide en la revisión específica de la Guerra Civil y el franquismo desde el punto de vista de los perdedores del conflicto, empleando la entrevista parcial o totalmente como centro neurálgico de su estructura y contenido. Dos ejemplos destacan como representativos de la globalidad ${ }^{20}$ : La vieja memoria (Jaime Camino, 1977) y ¿Por qué perdimos la guerra? (Diego Santillán y Luis Galindo Acevedo, 1978). Rodado con cierta urgencia resultante de la avanzada edad de muchos de los entrevistados y la dificultad añadida por la localización de algunos todavía en el exilio, La vieja memoria confronta los recuerdos de los protagonistas del periodo comprendido entre la declaración de la Segunda República y el final de la Guerra Civil trenzando un discurso colectivo sobre el desarrollo del conflicto que cuestiona radicalmente la versión del franquismo ${ }^{21}$.

La utilización de imágenes de archivo intercaladas permite abrir un debate que gira en torno a cuatro apartados temáticos: los éxitos y fracasos del periodo de gobierno de la república, el caótico desarrollo de la guerrilla urbana suscitada en Cataluña en julio de 1936, la reconstrucción de la defensa de Madrid ante el avance de las tropas nacionales en 1938, y la disyuntiva de llevar a cabo la revolución de forma simultánea a la guerra.

Su modelo enunciativo emplea la entrevista de forma novedosa al escamotear las preguntas y permitir que fluyan las respuestas con aparente naturalidad. Se crea así una estrategia para la presentación de los hechos que parece estar vinculada casi exclusivamente a la palabra de los entrevistados, pero que no impide detectar un meditado trabajo de montaje del material ${ }^{22}$. Por ejemplo, el empleo del inserto de forma interesada haciéndolo pasar por contraplano sirve para enfrentar testimonios contradictorios o construir reacciones cocinadas en la sala de edición: los dos protagonistas que se muestran en imagen parecen estar debatiendo en un mismo espacio, con lo que se potencia la dialéctica de sus discursos gracias a la continuidad generada por el rácord de mirada.

Los materiales audiovisuales que acompañan las entrevistas -imágenes de archivo, locuciones literarias, sonidos varios, música, pinturas y rótulos- también operan por montaje significaciones interesadas que dan prioridad a la voz del bando perdedor y estimulan la empatía e identificación del espectador con el mismo: el documento de corte épico en el que las columnas de milicianos catalanes voluntarios parten hacia Aragón, el pasaje hagiográfico de la figura de Buenaventura Durruti, las imágenes de los bombardeos del Alcázar de Toledo contrapuestas con las de un Franco victorioso, el melancólico violín que suena mientras las mujeres huyen dejando a los hombres en el frente de Madrid, el

20 Con diferentes pretensiones y logros, podríamos citar los siguientes títulos: ¡Arriba España! (José María Berzosa, 1976) indaga desde una perspectiva externa -es un encargo de la televisión pública francesa- en las consecuencias de la Guerra Civil; España debe saber (Eduardo Manzanos, 1976) revisa espinosos asuntos acontecidos durante los años bélicos como el asesinato de Federico García Lorca o la persecución sufrida por Julián Besteiro; Entre la esperanza y el fraude: España 1931-1939 (Cooperativa de Cine Alternativo, 1976-77) reflexiona sobre las actuaciones de los republicanos en el conflicto; Dolores (José Luis García Sánchez y Andrés Linares, 1980) propone un retrato humano de Dolores Ibárruri "La Pasionaria" no exento de opinión política; Les deux mémories (Jorge Semprún, 1974), estrenado en Francia tras su prohibición en España, recoge los testimonios de políticos, intelectuales, artistas y dirigentes de ambos bandos.

21 Cfr. VÉLEZ, Palmira, "La memoria de la guerra civil española en el cine de no ficción de la Transición: Canciones para después de una guerra y La vieja memoria", Congreso Internacional Hispanic Cinemas, [http://memoriatransicion.unizar.es/trabajos\%20 cientificos\%20del\%20equipo\%20investigador/PALMIRA_V_LEZ_ La_memoria_en_el_cine.pdf], Universidad Carlos III, Madrid, 2012 (última consulta: 17/12/2014).

22 BENET, Vicente José, "La nueva memoria: imágenes de la memoria en el cine español de la Transición", Anales, no 3-4 (20002001), p. 165. 
poema de Rafael Alberti dedicado a la defensa de la capital que acompaña las imágenes de las víctimas de los bombardeos o la inquietante mirada a cámara del futuro dictador que el realizador congela en el episodio de la caída de la retaguardia republicana, son ejemplos de ello.

Se construye así una memoria audiovisual que dialoga con la Historia, mediante la exposición de hechos y acciones, la reflexión, recapitulación, el juicio e incluso la controversia. ${ }^{23}$ Con todo, La vieja memoria hornea un recuerdo colectivo que no oculta el filtro ideológico de un relato focalizado desde el punto de vista de los perdedores de la contienda, lo que permite leer el filme como una metáfora -en el momento de tensiones que atravesaba la Transición española- de un país aún dividido en dos facciones y necesitado de una catarsis para cerrar las heridas del pasado.

Por su parte, el documental ¿Por qué perdimos la guerra? traza un recorrido cronológico de las razones de la derrota republicana, utilizando también la entrevista como base de su estructura. Sus protagonistas son militantes anarcosindicalistas de la Segunda República y la Guerra Civil, cuyos testimonios son trufados con imágenes de archivo del conflicto. Pero, en este caso, todos los entrevistados confirman desde su subjetiva polifonía lo que la autorizada voz en off verbaliza como verdad irrefutable, y de la misma forma todo el archivo que salpica las entrevistas corrobora sin contradicción el sentido de las palabras que el relato resultante de las instancias narradoras proporciona. Para contrarrestar esta pobreza semántica audiovisual, el documental sirve muchos minutos de imágenes de confrontación bélica, en ocasiones dotadas de una tremenda dureza para las víctimas del bando republicano, apelando así a la emoción y desgarro de los espectadores en su identificación con el sufrimiento de obreros y campesinos, y condenando el terror del ejército franquista en su papel del villano. La banda sonora también aporta emoción y dirige el sentido de las imágenes mediante el empleo del cancionero y la poesía representativa de las trincheras culturales opuestas al fran- quismo: Antonio Machado y su oda al desgarro de la capital titulada Madrid, Rafael Alberti y su homenaje a la resistencia de la plaza en Poema de la defensa de Madrid -leído por el propio poeta- o el texto de pretensiones legendarias de Antonio Agraz Ha muerto Durruti. Sin embargo, la visión sobre las diferencias abiertas en el seno de los partidos de izquierda es hagiográfica con la facción anarquista y achaca la culpabilidad de lo sucedido a la debilidad gubernamental republicana. Por ello, de forma arbitraria, la película evita la presencia de importantes figuras políticas de izquierdas cuyo protagonismo la Transición reconoció aún en vida -como "Pasionaria"- y otorga voz a personajes menores pertenecientes al POUM -Julián Gorkin, Víctor Alba o Eduardo Val- para ejercer una dura crítica sobre el comunismo y los sectores que representaron la burguesía republicana, haciéndoles responsables de la desunión del bando enfrentado a Franco.

El otro asunto sujeto a revisión en la rememoración del conflicto bélico y sus consecuencias atañe a Francisco Franco y su régimen dictatorial. Empleando la fórmula del metatexto cinematográfico -una película que comenta otra- Raza, el espíritu de Franco (Gonzalo Herralde, 1977) contrapone dos largas entrevistas realizadas a Pilar Franco Bahamonde, única hermana viva entonces de la familia, y al galán cinematográfico Alfredo Mayo, con diferentes secuencias del largometraje Raza (José Luis Sáenz de Heredia, 1942) en el que el actor interpretaba al personaje principal -José Churruca- y cuyo guión, firmado por el mismo Francisco Franco bajo el seudónimo de Jaime de Andrade, adaptaba el libro homónimo del dictador. En realidad, los fragmentos de película que salpican e interrumpen las entrevistas del documental de Herralde no pertenecen al negativo de los años cuarenta, sino que se toman prestados de El espíritu de una

\footnotetext{
23 TRANCHE, Rafael R., "Memoria y testimonio en el cine de Jaime Camino: de La vieja memoria (1977) a Los niños de Rusia (2001)", [http://www.uv.es/imagengc/articulos/Memoria\%20y\%20testimonio\%20en\%20el\%20cine\%20de\%20Jaime\%20Camino.pdf] (última consulta: 10/01/2015).
} 
raza (1952), la versión que el aparato franquista reestrenó diez años después con la intención de comedir los excesos ideológicos de la Guerra Civil para adaptarlos a una Europa donde los fascismos habían sido derrotados y el comunismo se presentaba como el enemigo emergente, y cuyo título modificado explica el juego de palabras que bautiza también la película de Herralde ${ }^{24}$.

Los primeros fragmentos escogidos de $\mathrm{El}$ espíritu de una raza presentan la infancia incontaminada de la familia Churruca en los albores del siglo XX: una madre abnegada, conciliadora, devota y entregada a las labores del hogar y al cuidado de sus tres hijos (Pedro, José e Isabel) espera pacientemente al marido, marino de profesión. A su llegada, el padre instruye moralmente a su prole narrando las hazañas bélicas de su antepasado, un valiente militar caído en la batalla de Trafalgar, en una clara anticipación de su propia suerte en la guerra de Cuba a la que será destinado inmediatamente. Este edificante relato se ve interrumpido por las declaraciones de Pilar Franco que, ajena al montaje en el que se insertarán sus palabras, refiere las vivencias de la familia Franco en el Ferrol de su infancia, evidenciando así la inspiración biográfica de la historia ficcional, pero trasluciendo a la vez una realidad más sombría: su padre, lejos del retrato del fiel esposo e intrépido militar se descubre como un simple administrativo de la armada que, distanciado de su mujer desde que es destinado a Madrid, se rodea de amantes fijas y ocasionales y muere tras sufrir diversos ataques de uremia.

Otros pasajes escogidos del filme de Sáenz de Heredia refieren la historia del enfrentamiento entre José Churruca y su hermano Pedro ya adultos al posicionarse en bandos opuestos durante la Guerra Civil. José es presentado en la película como un héroe patriótico que sobrevive milagrosamente a su propio fusilamiento, mientras que Pedro se construye como un politicastro republicano que en el último momento toma concien-

24 Cfr. FERNÁNDEZ-MAYORALAS, Juan, "Raza y Espíritu de una raza. Del fascismo al comunismo: La evolución de primer franquismo a través del cine", Educación y Medios (2007), pp. 33-40. cia de su miseria y se inmola por la causa de los nacionales.

El montaje en paralelo con los recuerdos que Pilar Franco verbaliza sugiere que estos personajes son trasuntos de Francisco y Ramón Franco respectivamente, a la par que deja entrever la distancia entre la sublimada ficción que manipula los acontecimientos y la verdadera historia familiar acontecida: si bien el dictador fue herido en África en una ocasión, lejos queda aquel pasaje de ser algo parecido a la mágica resucitación que propone el filme. Paralelamente, las declaraciones de la entrevista de Alfredo Mayo, grabadas en los escenarios que entonces albergaron el rodaje de la película, escinden al personaje que encarnó como soñado sosias de Franco del intérprete de carne y hueso dejando al desnudo sus pensamientos con respecto al ideario moral que la película edifica. Se muestra así ignorante y confuso con respecto a la consideración que de los almogávares da la película: una casta de guerreros elegidos que, según el discurso cinematográfico, representaba a la raza española. Distanciándose de la vocación militar y los valores que encarna su personaje -José Churruca- en la pantalla, el actor confiesa haberse incorporado al ejército durante la Guerra Civil por obligación, combatiendo en el bando nacional por una cuestión puramente pragmática y exenta de ideales.

La película de Sáenz de Heredia proponía una metáfora de la familia española desunida y un ensalzamiento de las gestas bélicas y la tradición marcial nacional del pasado ${ }^{25}$. La metaficción de Herralde, recién estrenada la Transición, se afana en desmontar esa condición totémica de la cinta bandera del movimiento mediante un ejercicio que escudriña el relato franquista en clave autobiográfica y familiar para que afloren sus fantasmas y se desenmascare la propaganda panfletaria del discurso programático de la posguerra española.

\subsection{Memorias militantes: reivindicaciones, alegatos y denuncias}

Un segundo lote de películas documentales reúne tres filmes que ejercen su rememoración 
sobre asuntos pretéritos desde una clara consciencia del presente en el que se realizan, para plantear reivindicaciones, alegatos o denuncias al calor de los tiempos de la Transición que vive el público al que se dirigen. El proceso de Burgos (Imanol Uribe, 1979) ${ }^{26}$ reconstruye el consejo de guerra sucedido en 1970 desde el punto de vista de los condenados. Su realizador confió en que la nueva mirada sobre el suceso permitiría profundizar en los conflictos derivados del nacionalismo de ETA desde una posición aséptica. Sin embargo, la presión ejercida entonces por las formaciones políticas nacionalistas, herederas de las consecuencias del proceso y enfrentadas en sus posturas ideológicas y morales ante el creciente fenómeno terrorista durante la Transición, presionaron para que el montaje final -y con ello el sentido del filme- fuese modificado. $\mathrm{El}$ aserto inicial en el que el diputado de Herri Batasuna Francisco Letamendia se esfuerza en legitimar el origen histórico de ETA se impuso como condición para que ese grupo político diera su visto bueno a la película y provocó que la cinta respaldase en su contenido sus tesis ideológicas. Igualmente, una última parte dedicada a la vida que los encausados llevaron tras el juicio desapareció de la versión final para ser sustituida por un montaje de fotografías fijas que orquestaban una imagen de tensión, protesta e inestabilidad en el País Vasco durante los años setenta, refrendando así la necesidad del apoyo popular como motor de las acciones de la izquierda abertzale ${ }^{27}$. En sus entrevistas, los integrantes de la banda son tratados como mártires en lucha contra el franquismo. Sus relatos incluyen siempre referencias a la opresión y los malos tratos de los verdugos del régimen: Itziar Aizpurua refiere que cuando la detuvieron en su propio domicilio pegaron a sus padres y a ella le rompieron dos costillas; más tarde, en el gobierno civil, la hicieron creer que su compañero Jokin había sido asesinado y la intimidaron mostrándole diversos instrumentos de tortura para que cooperase aportando información. En múltiples ocasiones a lo largo del filme esa supuesta condición de víctimas justifica el uso de la violencia de distin- tas formas. Mediante la dualidad nacionalista y revolucionaria en defensa de los trabajadores, como afirma Josu Abrizketa: "ETA era la única organización que respondía consecuentemente a esa opresión que sufrió el pueblo vasco, sobre todo en la época de Franco (...) al elemento que me captó le dije que cuando uno recibe una patada en los cojones hay que responder con una patada en los cojones". Desde el prisma religioso: como cuando el sacerdote Jon Etxabe defiende la posibilidad de la lucha armada como algo compatible para un creyente.

O bien considerando los crímenes de la organización como acciones de auténtica justicia, como evidencian las declaraciones de Xavier Izko de la iglesia al legitimar la decisión de asesinar a Melitón Manzanas: "Lo ejecutó una organización que asumía con toda la fuerza a un verdadero asesino del pueblo vasco, a un torturador desde el 36".

El hecho de que sean los propios protagonistas los encargados de narrar los hechos convirtió al filme en un documento histórico de valor excepcional ${ }^{28}$, pero también brindó una oportunidad a los radicales de izquierdas de rememorar lo sucedido hace una década y esgrimirlo para ensalzar y dar a conocer, desde la recién estrenada libertad de la amnistía democrática, una gesta pretérita que se propone como justificación histórica de las acciones de la organización y su entorno en el momento del estreno del filme.

El siguiente documental analizado se presenta al público como un alegato rodado en la clan-

\footnotetext{
25 GUBERN, Román, "Tres retratos de Franco", Archivos de la Filmoteca, no 42-43 (2002), p. 147

26 Sobre la génesis y la elaboración del documental, véase: ZUNZUNEGUI, Santos, El cine en el País Vasco, Diputación Foral de Bizkaia, Bilbao, 1985, pp. 251-253; y UGARTE, Javier, "Los orígenes documentales de Imanol Uribe: El proceso de Burgos", en La historia a través del cine (De Pablo, Santiago, ed.), Universidad del País Vasco, Bilbao, 2000, pp. 109-122.

27 Cfr. BARRENETXEA MARAÑÓN, Igor, "La trilogía vasca de Imanol Uribe: una mirada al nacionalismo vasco radical a través del cine", Ikusgaiak. Cuadernos de cinematografía, no 6 (2003), p. 78.

28 MALALAÑA UREÑA, Antonio y FERNÁNDEZ GONZÁLEZ, Gonzalo, "Eta y el cine. Las fuentes de información de los profesionales del cine", Revista general de información y documentación, vol. 16, no 2 (2006), p. 204.
} 
destinidad y estrenado una vez muerto Franco: Queridísimos verdugos (Basilio Martín Patino, 1977) emplea la entrevista para diseccionar desde la crónica negra todos los vértices que se dan cita en la teoría y praxis de la pena de muerte bajo la modalidad del garrote. Su arranque presenta a Antonio López ante la cámara como un hombre de extracción humilde, ladronzuelo a su pesar, voluntario en la División Azul y emigrante en Alemania, al que el hambre obligó a aceptar el trabajo del verdugo encargado de las ejecuciones con garrote vil en tiempos del franquismo. Conocemos después a Vicente Copete, ex legionario destinado en África, maletilla y, por la misma razón de necesidad, colega en el oficio de "ejecutor de sentencias". El tercero de los verdugos españoles y protagonista del filme es Bernardo Sánchez Bascuñana, franciscano frustrado, viudo apesadumbrado, ripioso ocasional y decano de la profesión. Juntos forman un patético y siniestro trio de entrevistados que, mientras comparten exceso de bebida en un típico mesón andaluz o pasean por la Alhambra granadina, vierten opiniones sobre su trabajo y rememoran con detalle algunas de las ejecuciones que les han marcado.

Una segunda línea narrativa del documental confluye con la primera al reconstruir destacados crímenes propios del tremendismo español de la época, para conectar la personalidad y los motivos de los acusados con la forma en la que cada uno de ellos afronta su destino en el garrote vil, a partir del testimonio del verdugo presente en cada ocasión. El tercer eje de la película trufa las entrevistas a los verdugos y la reconstrucción de los casos con otros dos discursos paralelos. Por una parte, una voz en off traza una fugaz y particular historia del garrote ilustrada con dibujos, grabados y fotografías representativas. Por otra, un psiquiatra, un oficial de prisiones, un especialista en genética y un abogado testifican en calidad de expertos profesionales para dar su punto de vista sobre algunos de los casos mencionados.

En 1973, el garrote vil estaba aún vigente en España, tal y como muestra el episodio dedicado a la ejecución -sucedida durante el rodaje- de
Pedro Martínez Expósito, o las inminentes ejecuciones de Salvador Puig Antich y Heinz Chez en marzo de 1974. Pero cuando se estrenó el filme, el 20 de abril de 1977, la pena de muerte ya no se aplicaba, por lo que la película, a pesar de la entusiasta acogida de la crítica, no conectó con el público que estrenaba la democracia. Tal vez porque Queridísimos verdugos no plantea una rememoración audiovisual de los mecanismos de represión y tortura empleados durante el franquismo.

Más bien construye un ejercicio antropológico sobre el arte de matar que señala a la humanidad en su conjunto como responsable. Si bien por momentos la película muestra aspectos de la naturaleza humana como la crueldad, el cinismo o la falta de escrúpulos, López Sierra, Copete y Sánchez Bascuñana, también son humanizados al presentarse como meros chivos expiatorios que la sociedad utiliza para limpiar sus trapos sucios, aprovechándose de su ignorancia y necesidad. Se impone así la idea de que los auténticos verdugos no son los ejecutores de las sentencias -o al menos no los únicos-, sino aquellos que desde la comodidad y lejanía del poder las dictan.

Además de la reivindicación y el alegato, el documental de la Transición también empleó la entrevista como un documento al servicio de la denuncia. La película Rocío (Fernando Ruiz Vergara, 1980) ejerce una severa crítica, desde una ideología marxista, de la apropiación de los ritos religiosos de la Iglesia católica afín al régimen franquista para asumir el control y alienar al campesinado andaluz. Según su discurso, el liderazgo antropológico ejercido por las hermandades las convierte en cómplices de la represión, ejemplificada en el filme mediante el recuerdo que uno de los entrevistados narra.

Se trata de la rememoración de un violento episodio acontecido en la localidad de Almonte: el centenar de asesinatos perpetrados contra los vecinos que se opusieron al levantamiento militar que detonó la Guerra Civil.

Cuando la película llegó a los cines en 1981, los hijos del fallecido José María Reales Carras- 
co -personaje señalado como el responsable de los asesinatos- se querellaron contra el director, la guionista, el productor y el vecino de Almonte Pedro Gómez Clavijo -autor de las declaraciones en el filme- por injurias graves.

En Sevilla, un juez prohibió su exhibición en territorio español, convirtiéndola en la primera película secuestrada judicialmente tras la aprobación de la Constitución española. Ruiz Vergara fue condenado en 1982 a dos meses y un día de arresto mayor y al pago de diez millones de pesetas. La consecuencia inmediata es la eliminación, en la nueva versión exhibible, de los fragmentos que hacían alusión al caso.

El director, obligado a acatar el veredicto, mantuvo más de tres minutos de silencio con una pantalla en negro y el número de la sentencia sustituyendo al material censurado. Posteriormente, frustrado por el desarrollo de los acontecimientos, optó por el exilio voluntario a Portugal ${ }^{29}$.

La peripecia sufrida en la exhibición de Rocío, además de un ejemplo de rememoración escamoteada a un conjunto de víctimas de la Guerra Civil con nombre y apellido, constituye un síntoma inequívoco de la vigencia de algunas prácticas puntuales de censura cinematográfica en la etapa de la Transición

\subsection{Memorias biográficas: la represión acumulada}

El tercer conjunto de documentales de entrevista emplea en su rememoración del pasado el recuerdo biográfico e íntimo de sus protagonistas, permitiendo extrapolar su experiencia a dos generaciones -una crepuscular y otra emergenteque coincidieron en el presente de la Transición. El asesino de Pedralbes (Gonzalo Herralde, 1978) se estructura en torno a una larga entrevista llevada a cabo en la prisión de Huesca a José Cerveto, asesino confeso del crimen, cometido en 1974, de un matrimonio de la alta burguesía catalana para el que trabajaba como criado en su casa de Pedralbes.

La focalización que propone $\mathrm{El}$ asesino de $\mathrm{Pe}$ dralbes convierte a Cerveto en el protagonista in- discutible del filme sin necesariamente considerarle en el rol narrativo del villano. Y de hacerlo, se encarga de dotarle de suficiente interés para seguir forzando una incómoda identificación de los espectadores con su papel de desvalido, de hombre abocado al crimen debido a la destrucciónmoral y psicológica a la que le ha sometido la sociedad cruel de la posguerra. José Luis Cerveto esasí retratado como un desgraciado que asesina a su antiguo patrón por su encarnación del poderque le ha torturado durante décadas.

Su relato verbal descubre un universo sórdido repleto de hospicios, abusos, desorden sexual, pobreza e ignorancia, sepultado por la propaganda del régimen franquista. Desde la actualidad de la Transición, su discurso reabre el debate en torno a la ineficacia de las políticas de asistencia y reinserción carcelaria de finales de los años setenta y confiere al protagonista -además del estatus de criminal mediático- el papel de altavoz con libertad expresiva para criticar la inutilidad del sistema punitivo estatal.

El segundo caso es $E l$ desencanto (Jaime Chávarri, 1976), pensado inicialmente como un corto y producido por Elías Querejeta, acaba convirtiéndose en uno de los documentales clave de la Transición por su uso del testimonio directo y su rememoración metafórica del pasado desde un marco familiar de intimidad. La inauguración en la villa de Astorga en agosto de 1974 de una estatua del poeta Leopoldo Panero, considerado por muchos como uno de los altavoces poéticos del franquismo, sirve como punto de arranque para presentar a los miembros de la familia $\mathrm{Pa}$ nero -viuda e hijos- diseccionando sus personalidades, exponiendo su pensamiento y dando cuenta de las turbulentas y complejas relaciones que mantuvieron tras la muerte del padre.

Michi -el hermano pequeño- asume el papel de entrevistador con el objetivo de conducir a los

29 El documental de José Luis Tirado El caso Rocío (2013) reconstruye el enjuiciamiento y posterior persecución del filme como un ejemplo de censura vigente durante la Transición. Véase DEL RíO, Ángel, ESPINOSA, Francisco y TIRADO, José Luis (eds.), El caso Rocío. La historia de una película secuestrada por la transición, Aconcagua libros, Sevilla, 2013. 
protagonistas a verbalizar ante la cámara sus historias familiares, tan sórdidas como fascinantes, que le sirven para certificar el final de su estirpe. Tras los bucólicos relatos de juventud de Felicidad Blanc -la viuda- y las disertaciones literarias y poéticas de Juan Luis -el hermano mayoraparece en escena el tercer hermano, Leopoldo, que desde la soledad de un bar madrileño o un banco del colegio de su infancia, va poco a poco desmontando la leyenda lustrosa de la familia Panero para denunciar el trato de un padre brutal, la paranoia y esquizofrenia de sus hermanos, la insensibilidad de la madre ante sus reiterados intentos de suicidio, o la cobardía familiar generalizada que le empujó a pasar una espantosa juventud recluido en distintos manicomios. Su disidencia ante cualquier romanticismo genealógico queda patente en sus declaraciones: "La leyenda épica es lo que me figuro que se habrá contado aquí, en esta película, pues debe ser muy bonita y lacrimosa. Pero la verdad es una experiencia bastante... en fin, deprimente".

La película funciona como una metáfora de la decadencia aplicable a la familia tradicional española, antes de que ese deterioro se hubiera hecho patente para la sociedad protagonista de la Transición ${ }^{30}$. Su título además representó de forma simbólica, sin que existiese tal intencionalidad por parte de los responsables del filme, el sentimiento de decepción de aquellos que habiendo anhelado la llegada de la democracia no vieron cumplidas sus expectativas durante el periodo de cambios políticos al sentir que la memoria histórica había sido pasto del olvido ante la necesidad de facilitar el consenso a todas las partes.

Cierra nuestro análisis Ocaña, retrato intermitente (Ventura Pons, 1978), un fresco biográfico del pintor y artista homosexual José Ocaña basado en la provocación del recuerdo vivencial, que funciona como sinécdoque del deseo de libertad de expresión y transigencia en cuestiones de moral que la Transición trajo consigo. El documental alterna una larga entrevista en la que el protagonista rememora en primera persona sus vivencias y expresa sus pensamientos más íntimos, con distintas actuaciones -números musicales, piezas teatrales, exposiciones pictóricas y performances- en las que el protagonista del filme da rienda suelta a su particular visión de algunos imaginarios de la cultura popular española. José Pérez Ocaña llega a Barcelona en 1973 y en una década se convierte en un personaje destacado dentro de la escena contracultural del país.

Su elección como protagonista permite a la película abordar con valentía temas tabú en el cine español documental hasta ese momento, siendo la represión soportada por los homosexuales al que más atención dedica en su relato: "Yo soy un marginado, como las putas, como los chulos, como los maricones, como los ladronzuelos que te roban la moto". La discriminación de los gay nace, según Ocaña, del machismo reinante que impone la heterosexualidad como único comportamiento admisible: "Lo normal era ser macho", comenta al referirse a su infancia. La referencia al poeta García Lorca como ejemplo de mártir de la causa gay -"Le mataron con dos tiros en el culo porque era homosexual"-, o el señalamiento de la Iglesia como ente responsable de la homofobia -"La iglesia te había engañado mucho y te había metido miedo cuando hacías el amor, porque si ibas con un hombre estabas condenado al infierno seguro"-, refrendan su denuncia.

Frente a esta marginación evidente, Ocaña se rebela mediante gestos que hibridan la expresión artística y la pura provocación, siendo el striptease la acción catártica y liberadora que caracteriza su presencia en los lugares públicos. La represión sufrida da paso a la práctica del sexo como algo salubre y ajeno a ideología o moral alguna: "Cuando la gente se pone histérica y le entran paranoias, es porque la gente no folla o no hace el amor". En su discurso, comerciar con el cuerpo deja de ser algo ilícito o sucio, re-

30 Cfr. SÁNCHEZ NORIEGA, José Luis, "La (de)construcción fílmica de la familia Panero", Astorica. Revista de estudios, documentación, creación y divulgación de temas astorganos, no 31 (2012), p. 212. 
cuperando las prostitutas el protagonismo de la Magdalena bíblica al ejercer una misión social de primer orden, como la que lleva a cabo su amiga María: "Allí está, en las Ramblas, dando color y alegría a toda a gente que pasa por la calle; gente que necesita un poco de alegría, porque están grises".

Su decidido apoyo a la causa gay se cierra con la asistencia, reconstruida a través de una serie de instantáneas, a la manifestación de la asociación de gays catalana FAGC, que nos recuerda que en 1978 aún estaba vigente la Ley de Peligrosidad Social impuesta por Franco en 1970 para el control de los elementos considerados antisociales, entre los que se incluía a los homosexuales -con penas que podían llegar a los cinco años de internamiento en cárceles o centros psiquiátricos-. Desde esta perspectiva, sus testimonios y actitudes en el filme se pueden interpretar como evidencias de la represión acumulada por la sociedad de finales de los setenta, pasto aún de la educación e ideología impuesta por el régimen recién extinto.

\section{CONCLUSIONES}

La rememoración del documental de entrevista de la Transición española contribuyó al cambio democrático mediante una reelaboración del relato histórico previo en la que los perdedores de la Guerra Civil tuvieron un claro altavoz terapéutico: la polifonía del recuerdo colectivo y bronco de La vieja memoria funcionó como catarsis para que una de las dos Españas aún escindidas en el tiempo de la Transición -la de los perdedores de la contienda- pudiese curar sus heridas y mostrar su condición de víctima; ¿Por qué perdimos la guerra? advirtió sobre el peligro de la desunión de la izquierda en pleno proceso de transito democrático, al rememorar ese asunto como una de las claves de la victoria de la derecha en el pasado; y Raza, el espíritu de Franco ayudó a desenmascarar el ideario panfletario del régimen y hacer tambalear el mito marcial y humano del caudillo, apenas dos años después de su muerte.
Esa rememoración también planteó reivindicaciones, alegatos y denuncias desde la efervescencia del debate de la lucha por las libertades de la Transición: El proceso de Burgos buscó una legitimación del origen y las acciones violentas de la izquierda abertzale en el convulso paso a la década de los ochenta; Queridísimos verdugos tejió un alegato antropológico contra la pena de muerte con las últimas ejecuciones de garrote en España aún cercanas en el tiempo, presentando a los verdugos como marionetas anacrónicas fruto del régimen que dictaba las sentencias; por su parte, la denuncia de Rocío no consiguió restituir inmediatamente la memoria histórica de las víctimas de la Guerra Civil señaladas, pero dio cuenta de la existencia de nuevas formas de censura en el gobierno que capitaneó la Transición.

Por último, la rememoración de las biografias íntimas ayudó también a que aflorase la represión acumulada por sus protagonistas particulares durante los años de la dictadura, convirtiéndose en símbolos de la sociedad crepuscular a la que pertenecían: la decadencia familiar de El desencanto subrayó el anacronismo de toda una clase social extinta en los tiempos del cambio; El asesino de Pedralbes hizo emerger un monstruo que amenazaba la comunidad, fruto de la falta de educación imperante en la posguerra -que comienza a mostrarse entonces como un periodo histórico negro y deprimente-; y Ocaña, retrato intermitente sacó a flote la represión sufrida por el colectivo homosexual en el pasado, mostrando su deseo de formar parte de la nueva sociedad democrática por construir. 


\section{BIBLIOGRAFÍA}

BARRENETXEA MARAÑÓN, Igor, "La trilogía vasca de Imanol Uribe: una mirada al nacionalismo vasco radical a través del cine", Ikusgaiak. Cuadernos de cinematografía, n० 6 (2003), pp. 77-101.

BENET, Vicente José, "La nueva memoria: imágenes de la memoria en el cine español de la Transición", Anales, no 3-4 (2000-2001), pp. 159-174.

DEL ÁGUILA, Rafael, "Desmemoria y rememoración: la guerra y el franquismo hoy", Historia y Política, no 16 (2006), pp. 183-208.

DEL RÍO, Ángel, ESPINOSA, Francisco y TIRADO, José Luis (eds.), El caso Rocío. La historia de una película secuestrada por la transición, Aconcagua libros, Sevilla, 2013.

FERNÁNDEZ-MAYORALAS, Juan, "Raza y Espíritu de una raza. Del fascismo al comunismo: La evolución de primer franquismo a través del cine", Educación y Medios, (2007) pp. 33-40.

FERRO, Marc, Historia contemporánea y cine, Ariel, Barcelona, 1995.

GARCÍA MARTÍNEZ, Alberto N., "El film de montaje, una propuesta tipológica", Secuencias: revista de historia del cine, no 23 (2006), pp. 67-83.

GÓMEZ VAQUERO, Laura, Las voces del cambio. La palabra en el documental de la Transición en España, Ayuntamiento de Madrid, Madrid, 2012.

GUBERN, Román, "Tres retratos de Franco", Archivos de la Filmoteca, no 42-43 (2002), pp. 145-155.

HALBWACHS, Maurice, La mémoire collective, P.U.F., Paris, 1968.

HERNÁNDEZ RUIZ, Javier y PÉREZ RUBIO, Pablo, Voces en la niebla. El cine durante la transición española (19731982), Paidós, Barcelona, 2004.

HUGUET, Montserrat, "La memoria visual de la historia reciente", en La mirada que habla: cine e ideología (Camarero Gómez, Gloria, ed.), Akal, Madrid, 2002, pp. 8-22.

JULIÁ, Santos, Elogio de la Historia en tiempo de Memoria, Marcial Pons-Fundación Alfonso Martín Escudero, Madrid, 2011.

MALALAÑA UREÑA, Antonio y FERNÁNDEZ GONZÁLEZ, Gonzalo, "Eta y el cine. Las fuentes de información de los profesionales del cine", Revista general de información y documentación, vol. 16, no 2 (2006), pp. 195-216.

MONTERDE, José Enrique, Veinte años de cine español. Un cine bajo la paradoja (1973-1992), Paidós, Barcelona, 1993.

NORA, Pierre (ed.), Les lieux de mémoire, Gallimard, Paris, 1997.
PALACIO, Manuel, "Introducción", en El cine y la transición política en España (1975-1982) (Palacio, Manuel, ed.), Biblioteca Nueva, Madrid, 2011, pp. 7-18.

PÉREZ PERUCHA, Julio y PONCE, Vicente, "Algunas instrucciones para evitar naufragios metodológicos y rastrear la Transición democrática en el cine español", en El cine y la transición política en España (1975-1982) (Palacio, Manuel, ed.), Biblioteca Nueva, Madrid, 2011, pp. 223-268.

ROSENSTONE, Robert. A., El pasado en imágenes. El desafío del cine a nuestra idea de la historia, Ariel, Barcelona, 1997.

RUIZ TORRES, Pedro, "Los discursos de la memoria histórica en España", Hispania Nova. Revista de Historia contemporánea, no 7 (2007), [http://hispanianova.rediris. es/7/dossier/07d001.pdf]

SÁNCHEZ NORIEGA, José Luis, Historia del cine. Teoría y géneros cinematográficos, fotografía y televisión, Alianza editorial, Madrid, 2001.

SÁNCHEZ NORIEGA, José Luis, "La (de)construcción fílmica de la familia Panero", Astorica. Revista de estudios, documentación, creación y divulgación de temas astorganos, no 31 (2012), pp. 209-222.

SÁNCHEZ NORIEGA, José Luis (ed.), Filmando el cambio social. Las películas de la Transición, Laertes, Barcelona, 2014.

TODOROV,Tzvetan, Los abusos de la memoria, Paidós, Barcelona, 2000.

TRANCHE, Rafael R., "Memoria y testimonio en el cine de Jaime Camino: de La vieja memoria (1977) a Los niños de Rusia (2001)", [http://www.uv.es/imagengc/articulos/ Memoria\%20y\%20testimonio\%20en\%20el\%20 cine\%20de\%20Jaime\%20Camino.pdf]

UGARTE, Javier, "Los orígenes documentales de Imanol Uribe: El proceso de Burgos", en La historia a través del cine (De Pablo, Santiago, ed.), Universidad del País Vasco, Bilbao, 2000, pp. 109-122.

VÉLEZ, Palmira, "La memoria de la guerra civil española en el cine de no ficción de la Transición: Canciones para después de una guerra y La vieja memoria", Congreso Internacional Hispanic Cinemas, Universidad Carlos III, Madrid, 2012. [http://memoriatransicion.unizar. es/trabajos\%20cientificos\%20del\%20equipo\%20 investigador/PALMIRA_V_LEZ_La_memoria_en_el_cine.pdf] ZUNZUNEGUI, Santos, El cine en el País Vasco, Diputación Foral de Bizkaia, Bilbao, 1985. 